Article

\title{
Analysis of Dry Spells in Southern Italy (Calabria)
}

\section{Tommaso Caloiero ${ }^{1}$, Roberto Coscarelli ${ }^{2}$, Ennio Ferrari ${ }^{3, *}$ and Beniamino Sirangelo ${ }^{4}$}

1 National Research Council-Institute for Agricultural and Forest Systems in Mediterranean (CNR-ISAFOM), Via Cavour 4/6, Rende (CS) 87036, Italy; E-Mail: tommaso.caloiero@isafom.cnr.it

2 National Research Council-Research Institute for Geo-Hydrological Protection (CNR-IRPI), Via Cavour 4/6, Rende (CS) 87036, Italy; E-Mail: coscarelli@irpi.cnr.it

3 Department of Computer Engineering, Modelling, Electronics, and Systems Science (DIMES), University of Calabria, Via P. Bucci 41C, Rende (CS) 87036, Italy

4 Department of Environmental and Chemical Engineering (DIATIC), University of Calabria, Via P. Bucci 41C, Rende (CS) 87036, Italy; E-Mail: beniamino.sirangelo@unical.it

* Author to whom correspondence should be addressed; E-Mail: ennio.ferrari@unical.it; Tel.: +39-0984-496618.

Academic Editor: Athanasios Loukas

Received: 30 April 2015 / Accepted: 8 June 2015 / Published: 17 June 2015

\begin{abstract}
A deficit in precipitation may impact greatly on soil moisture, snowpack, stream flow, groundwater, and reservoir storage. Among the several approaches available to analyze this phenomenon, one of the most applied is the analysis of dry spells. In this paper, an investigation of the spatial and temporal patterns of dry spells, in a region of southern Italy, has been carried out on a daily precipitation dataset. First, the frequency distributions of the sequences of dry days have been analyzed. Then, the regional areas most affected by dry events have been evaluated at annual and seasonal scale. Finally, the long-term trend of the dry spells has been estimated at annual and seasonal scale. Results show that the lower probabilities of long dry spells occur in the main reliefs of the region, while the highest values have been detected in the Ionian side. The spatial distribution of the mean and maximum length values of the dry spells evidenced a west-east gradient. The trend analysis mainly revealed a negative behavior in the duration of the dry spells at annual scale and a positive trend in the winter period.
\end{abstract}

Keywords: dry spells; trend; Calabria 


\section{Introduction}

Following the increase in anthropogenic greenhouse gas concentrations, numerous studies on climate change have detected an important tendency towards a global warming in the last decades [1], with changes in precipitation regimes [2,3] as well as in storm tracks [4,5]. Precipitation variability occurs over a wide range of temporal and spatial scales. Several studies conducted at global [6,7], regional [8,9], and sub-regional scales [10-12] have evidenced growing precipitation change at different timescales. In particular, yearly rainfall increments in Northern and Central Asia, in the eastern parts of North and South America, and in Northern Europe [13-15] have been detected. By contrast, other areas, such as the Mediterranean area, have shown a decrease in precipitation [16-20]. In southern Italy [21], and particularly in the Calabria region [22-27], different studies highlighted a decreasing trend in winter and autumn rainfall, and an increasing trend in spring and summer.

Research on the changing patterns of the regional and local-scale precipitation is very important for the assessment of hydrological consequences, such as flooding and droughts in the context of climate change. In particular, droughts are expected to become more frequent, as a result of the predicted modification of the hydrological cycle [28-31] and of the rainfall decrease observed in the Mediterranean basin, with severe consequences on agricultural yield losses and water shortages [32,33]. Moreover, dry conditions also damage natural ecosystems [34,35] and forestry [36,37] and lead to soil degradation and desertification [38,39], social alarm [40], and famine and impoverishment [41,42]. Usually, drought indices are useful for monitoring and assessing these phenomena since they facilitate communication of climate anomalies to diverse user audiences; they also allow scientists to assess quantitatively climate anomalies in terms of their intensity, duration, frequency, recurrence probability and spatial extent $[43,44]$. However, among the several approaches available to analyze this phenomenon, one of the most applied is the analysis of dry spells. A dry spell is defined as the number of consecutive days with a daily precipitation amount below a certain threshold, such as $0.1,1,5,10 \mathrm{~mm}$, preceded and followed by at least one day with rainfall exceeding the threshold [45,46]. In the last decades, numerous analyses related to dry spell lengths have been applied in different areas, such as North [47] and South America [48,49], Asia [50-52], Europe [53-56], the Mediterranean basin [57-59], and Italy [60,61]. In particular, the results obtained by the authors of [57] indicated an increase in the mean and largest dry periods over a great part of the Iberian Peninsula, with a south-north gradient. In Greece, The authors of [58] evidenced high values of consecutive dry days in the Cyclades Islands and the southeastern Aegean Sea, while minimum values were found in the northwestern Greece. The authors of [59] divided Croatia into three main climatological regions: the highlands with the shortest dry spells, the coastal region with the longest dry spells, and the mainland with intermediate values. Furthermore, the authors of [59] evidenced a prevailing positive trend of both mean and maximal durations during winter and spring seasons and a negative trend in autumn. In Italy, the analysis of drought trends, performed by an index estimating the proportion of dry days in each season, showed a remarkable increase in winter droughts [60]. Moreover, with regards to long dry spells, in few rain gauges in the Calabria region, the authors of [61] evidenced greater probabilities to observe a dry spell in 1981-2010 than in 1951-1980.

The aim of this study is to analyze the spatial patterns and temporal variability of dry spells in a region of southern Italy (Calabria). In particular, the main objectives of this paper are: 
(i) the spatial analysis of the frequency distributions of the sequences of dry days;

(ii) the evaluation, at annual and seasonal scale, of the regional areas most affected by dry events; and

(iii) the estimation, at annual and seasonal scale, of the long-term trend of the dry spells.

\section{Materials and Methods}

Calabria is a region of Southern Italy with an area of $15,080 \mathrm{~km}^{2}$; its mean altitude is $597 \mathrm{~m}$ a.s.1. and its maximum elevation is $2266 \mathrm{~m}$ a.s.1. Although there are not many high summits in the region, it can be considered as one of the most mountainous in Italy. In fact, $42 \%$ of the land is mountainous (elevation greater than $500 \mathrm{~m}$ a.s.1.), 49\% hilly (elevation between 50 and $500 \mathrm{~m}$ a.s.1.) and only 9\% has an elevation lower than $50 \mathrm{~m}$ a.s.1. (Figure 1).

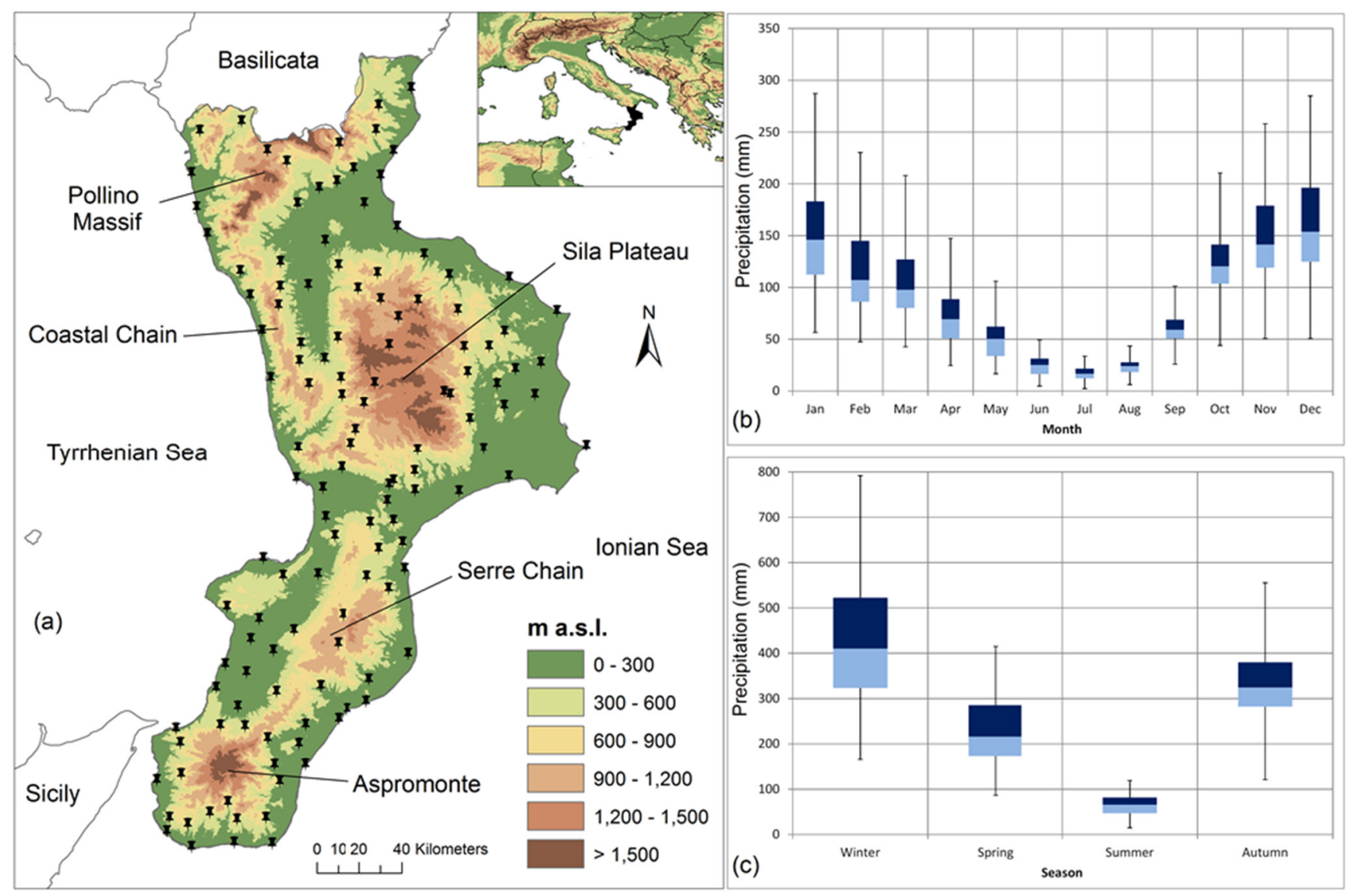

Figure 1. (a) Location of the selected stations on a Digital Elevation Model (DEM) of Calabria; (b) regional monthly precipitation distribution; and (c) regional seasonal precipitation distribution.

The Mediterranean climate characterizes this area. The region has high climatic contrasts, due to its geographic position and mountainous nature. Particularly, the Ionian side is influenced by warm air currents coming from Africa and high temperatures, with short and heavy rainfalls. Since the Tyrrhenian side is influenced by western air currents, it presents milder temperatures and mainly orographic precipitation. In the inland zones, colder winters with snow, and cooler summers with some precipitation are observed [62]. 
The starting data used in this study were a set of daily precipitation series for the period 1916-2006, registered in Calabria and collected by the former Italian Hydrographic Service, now Centro Funzionale Multirischi of Regione Calabria. Particular attention has been given to the problems deriving from the inhomogeneities of the data series and from the lack of data and the final database used in this study was the one presented in [24]. In order to remove inhomogeneities, the Craddock test [63] has been used. In particular, instead of using one single reference series (obtained as the average among the neighboring stations), each series was tested against the other series, by means of a multiple application of the Craddock test [63], in sub-groups of ten series. The estimation of the missing data was performed by exploiting a two-step procedure, proposed by [64], which preserves both the correct event time location (wet/dry days) and the statistical properties of daily precipitation series. At the end of the data processing, a total of 129 daily rainfall series were available for the analysis (Figure 1). With the aim to allow an analysis of rainfall series with equal length and pertaining to the same period, only the period 1941-2006 has been considered.

In the analyses of dry spells, various statistical indicators have been used by different authors. Among these, the most common indicators used are the mean and the maximum length of dry spell [65]. In this paper, for each of the 129 daily rainfall series, the dry spells have been detected and the mean length of dry spell and maximum length of dry spells have been evaluated. The term dry spell of length $n$ days is defined as a succession of $\mathrm{n}$ consecutive days below a certain threshold of rain, preceded and followed by days with rain. The authors of [66] used the daily rainfalls of 0.1 and $1 \mathrm{~mm}$ to see whether threshold values influence dry spell distributions. The authors of [67] emphasized that using the $10 \mathrm{~mm}$ threshold eliminates situations where a few isolated rainy days with small precipitation volumes can break an otherwise long dry spell. The authors of [68,69] also used a $5 \mathrm{~mm}$ threshold. In the present study, a day without rain has been considered as one in which the record registers a precipitation amount below a threshold of $0.1 \mathrm{~mm}$ and the occurrence of each dry spell has been ascribed to the last day of the sequence. Moreover, the meteorological year was considered, since there is a high probability to have rainy days at the end or at the beginning of each year, due to the climate characteristics of the study area.

In order to determine the possible existence of temporal tendencies in the maximum duration of the dry spells, annual and seasonal series were analyzed for trends, and their statistical significance assessed with the Mann-Kendall (MK) non-parametric test [70,71]. The slopes of the trends were calculated by least square linear fitting. The MK test is a rank-based method for evaluating the presence of trends in time-series data, without specifying whether the trend is linear or non-linear. The data are ranked according to time, and then each data point is compared to all the data points that follow in time. The MK statistic [71] is given by:

$$
S=\sum_{i=1}^{n-1} \sum_{j=i+1}^{n} \operatorname{sgn}\left(x_{j}-x_{i}\right)
$$

where $x$ are the data value at times $i$ and $j, n$ is the length of the data set and $\operatorname{sgn}(z)$ is equal to $+1,0$, and -1 when $z$ is greater than, equal to, or less than zero, respectively. Under the null hypothesis that $x_{i}$ are independent and randomly ordered, for $n$ greater than 8 , the statistic $S$ is approximately normally distributed with zero mean and variance: 


$$
\operatorname{Var}(S)=\left[n(n-1)(2 n+5)-\sum_{i=1}^{n} t_{i} i(i-1)(2 i+5)\right] / 18
$$

where $t_{i}$ denotes the number of tied values of extent $i$.

The standardized test statistic $Z$, computed by:

$$
Z_{\mathrm{MK}}=\left\{\begin{array}{cc}
\frac{\mathrm{S}-1}{\sqrt{\operatorname{Var}(S)}} & \text { for } S>0 \\
0 & \text { for } S=0 \\
\frac{\mathrm{S}+1}{\sqrt{\operatorname{Var}(S)}} & \text { for } S<0
\end{array}\right.
$$

follows a standard normal distribution [71].

The probability value, $p$, of the $Z_{M K}$ statistic of sample data can be estimated using the normal cumulative distribution function $\Phi\left(Z_{M K}\right)$ :

$$
\mathrm{p}=1-\Phi\left(Z_{M K}\right)=1-\frac{1}{\sqrt{2 \pi}} \int_{0}^{Z_{M K}} \mathrm{e}^{-t^{2} / 2} \mathrm{~d} t
$$

At the significance level $\alpha$, the existing trend is considered to be statistically significant if $p \leq \alpha / 2$ in the case of the two-tailed test.

The presence of a serial correlation in the hydrological time series changes the rate of rejecting the null hypothesis of no trend [72]. It particularly alters the variance of the MK statistic, whereas it does not alter its mean and its distribution type [73], thus leading to a disproportionate rejection of the null hypothesis of no trend when it is true. In order to avoid such error, the serial correlation/lag-1 correlation needs to be checked in the datasets before applying the non-parametric MK test. Usually, to reduce the influence the serial correlation, the pre-whitening procedure suggested by [74] is applied:

$$
Y_{t}=X_{t}-r_{1} \cdot X_{t-1}
$$

where $Y_{t}$ is the pre-whitened series, $Y_{t}$ is the sample series and $r_{1}$ is the lag- 1 serial correlation coefficient of the sample data, that can be expressed as:

$$
r_{1}=\frac{\frac{1}{n-1} \sum_{t=1}^{n-1}\left[X_{t}-E\left(X_{t}\right)\right]\left[X_{t+1}-E\left(X_{t}\right)\right]}{\frac{1}{n} \sum_{t=1}^{n}\left[X_{t}-E\left(X_{t}\right)\right]^{2}}
$$

where $E\left(X_{t}\right)$ is the mean of the sample data. The authors of [74] demonstrated that pre-whitening operation is not necessary for $r_{1} \leq 0.1$.

\section{Results and Discussion}

\subsection{Characteristics of Dry Spell}

With the aim to analyze the probability distribution of the dry spell durations, the 90th, 95th and 99th percentile of each series have been identified and mapped (Figure 2). 
As expected, the distribution of the dry spells is strictly related to the orography and to the climatic characteristics of the region. In fact, as [75] found out, orography influences the rainfall amount and its distribution over the region, thus explaining the different values between the two seacoasts of Calabria. The authors of [75] also showed that the interaction between orography and the mesoscale circulations leads to a precipitation gradient between the Tyrrhenian and Ionian sides of the Calabrian peninsula. As a result, the areas with the lowest percentile, which means lower probabilities of long dry spells, have been identified in the main reliefs of the region, and particularly in the Pollino Massif (18 and 33 days for 95th and 99th percentiles, respectively) and in the Serre Chain (12 and 18 days for 90th and 95th percentiles, respectively). Conversely, on the Ionian side of the region, which is characterized by short and heavy rainfalls, the highest values have been detected (22, 35 and 93 days for 90th, 95th and 99th percentiles, respectively). On the Tyrrhenian side, which is mainly affected by orographic precipitation, only small areas have shown high values, but always lower than the ones detected on the Ionian side.

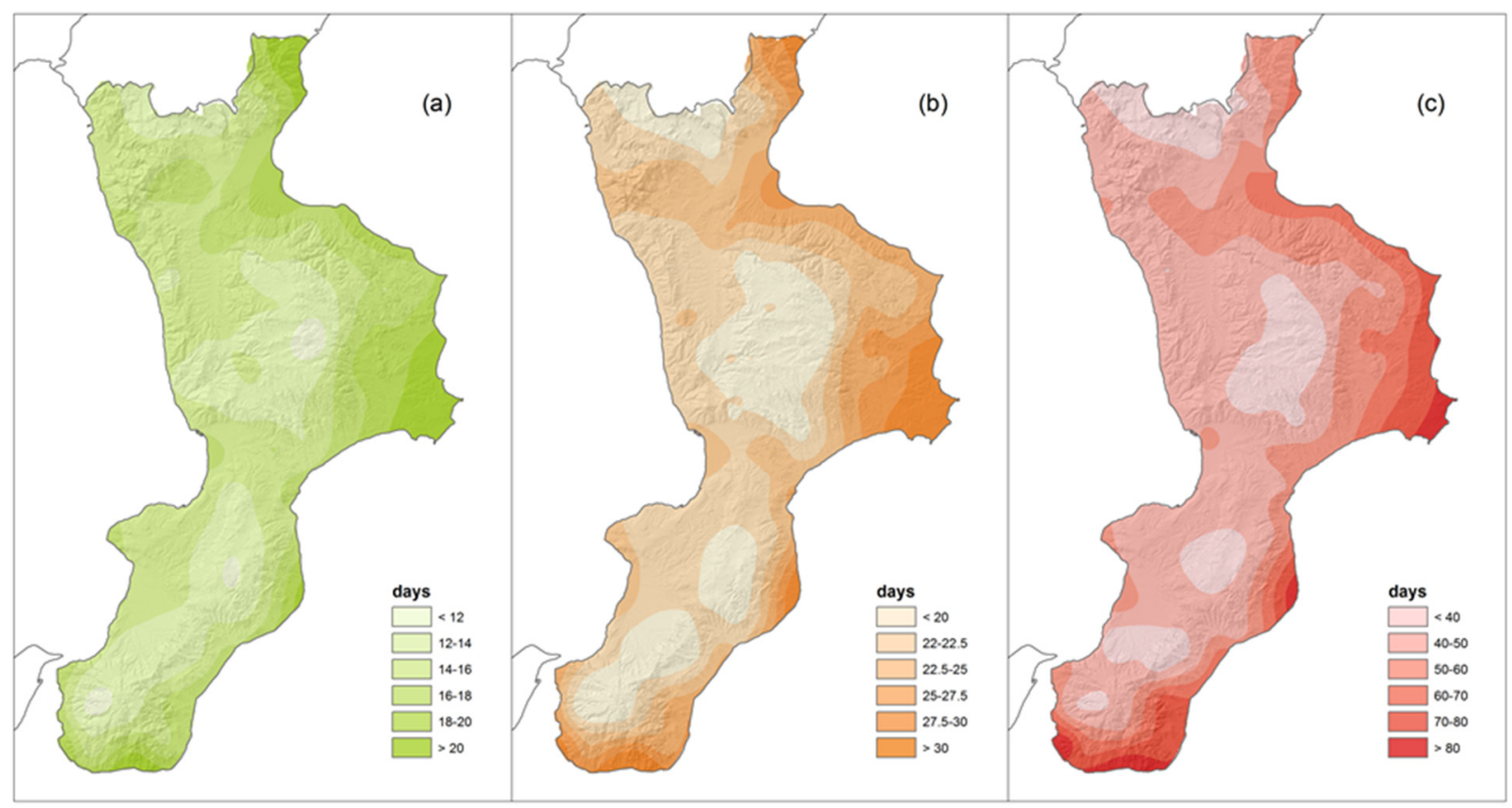

Figure 2. Spatial distributions of the (a) 90th; (b) 95th and (c) 99th percentiles of the dry spell durations.

\subsection{Average and Maximum Lengths of Dry Spells}

The yearly average and the maximum length of the dry spells are presented in Figure 3. By observing the spatial distribution of the mean length values on the Calabria region (Figure 3a), the study area can be divided in two parts: the western side of the region with mean values ranging between six and eight days, and the eastern side with the highest mean values (between eight and ten days). The lowest mean values (between four and six days) have been detected in the Sila Plateau, in the Serre Chain and in Aspromonte. These results confirm the ones obtained by [76], which identified an east-west gradient in the daily rainfall distribution, with a high rainfall concentration in the eastern side of the region, and a more homogenous temporal distribution of the rainfall in the western side. 
As the authors of [48] evidenced, the maximum length of dry spells is an extreme and instability property but its analysis may reveal interesting results (Figure 3b). The most notable effects of the maximum length analysis are the confirmation of the west-east gradient and, moreover, the identification of the highest values (more than 200 days) in the plain areas of the region. In fact, these areas are the most economically important agricultural areas of the region, and long dry periods can be quite harmful to crops because of water or moisture shortage.

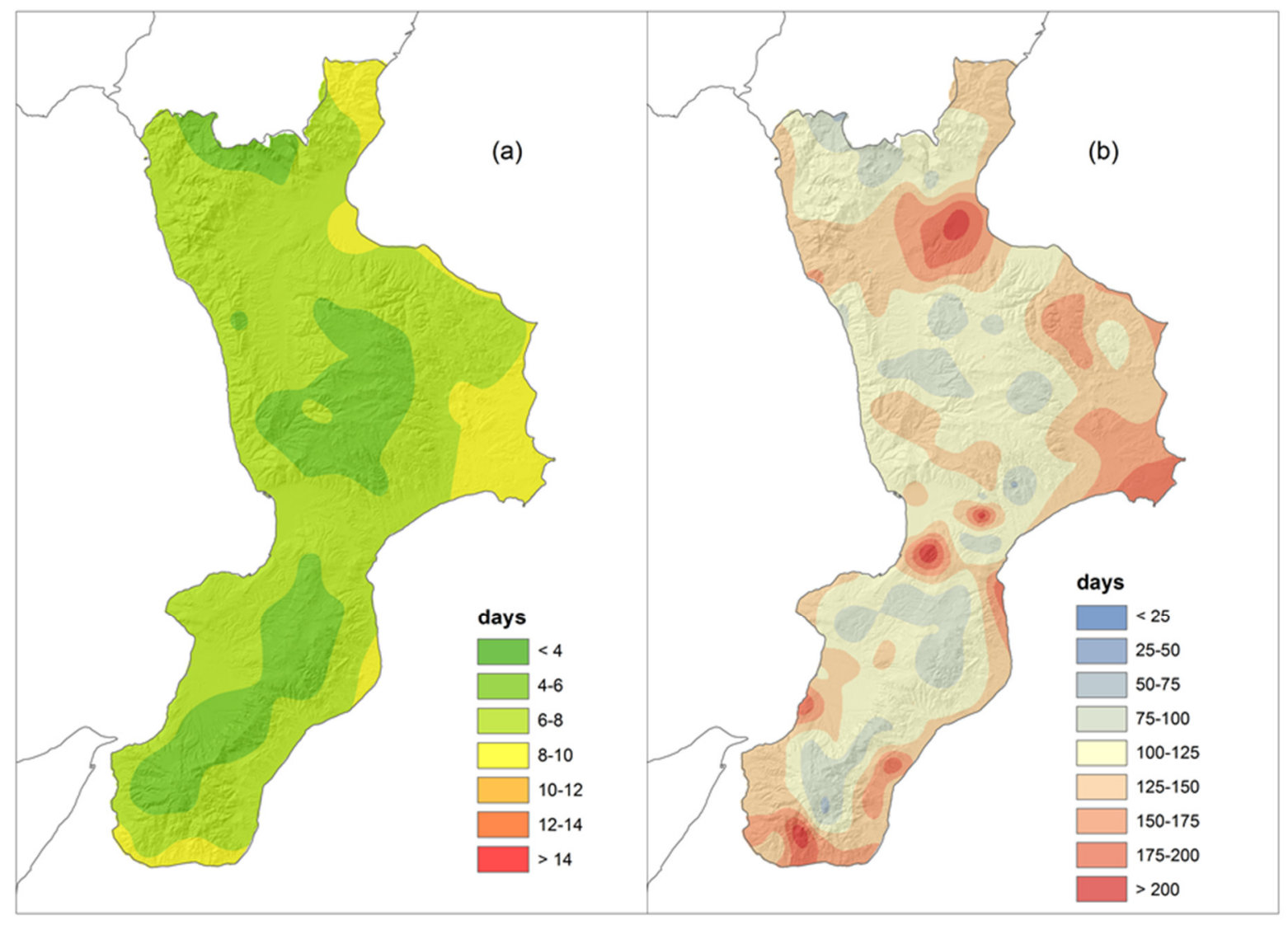

Figure 3. (a) Yearly mean and (b) maximum length of the dry spells in the observation period.

As to what concerns the mean length of the dry spells on a seasonal basis, the annual pattern is mainly reflected in autumn (Figure 4d), but with higher values. In fact, in autumn the west-east gradient is confirmed (ranging from five to twelve days), together with the lowest values detected in the Sila Plateau, in Aspromonte and particularly in the Serre Chain. By contrast, due to the Mediterranean climate, which is characterized by high rainfall in winter (Figure 1), in this period there is not such a difference between the two sides of the region (Figure 4a). In spring, the region can be divided in two areas, the coastal Ionian and southern Tyrrhenian areas with the highest mean dry spells durations (about nine days), and the central and northern Tyrrhenian area with the lowest ones (about nine days) (Figure 4b). In summer, when precipitation is less frequent (Figure 1), the highest average values among the different seasons have been detected. In particular, almost the entire region showed dry spells longer than 14 days (up to about thirty days in the most southern part of the region), with the exception of the mountainous areas, which presented values ranging between eight days, in the higher summits of the Sila Plateau and of the Pollino Massif, and 14 days for lower elevations. 


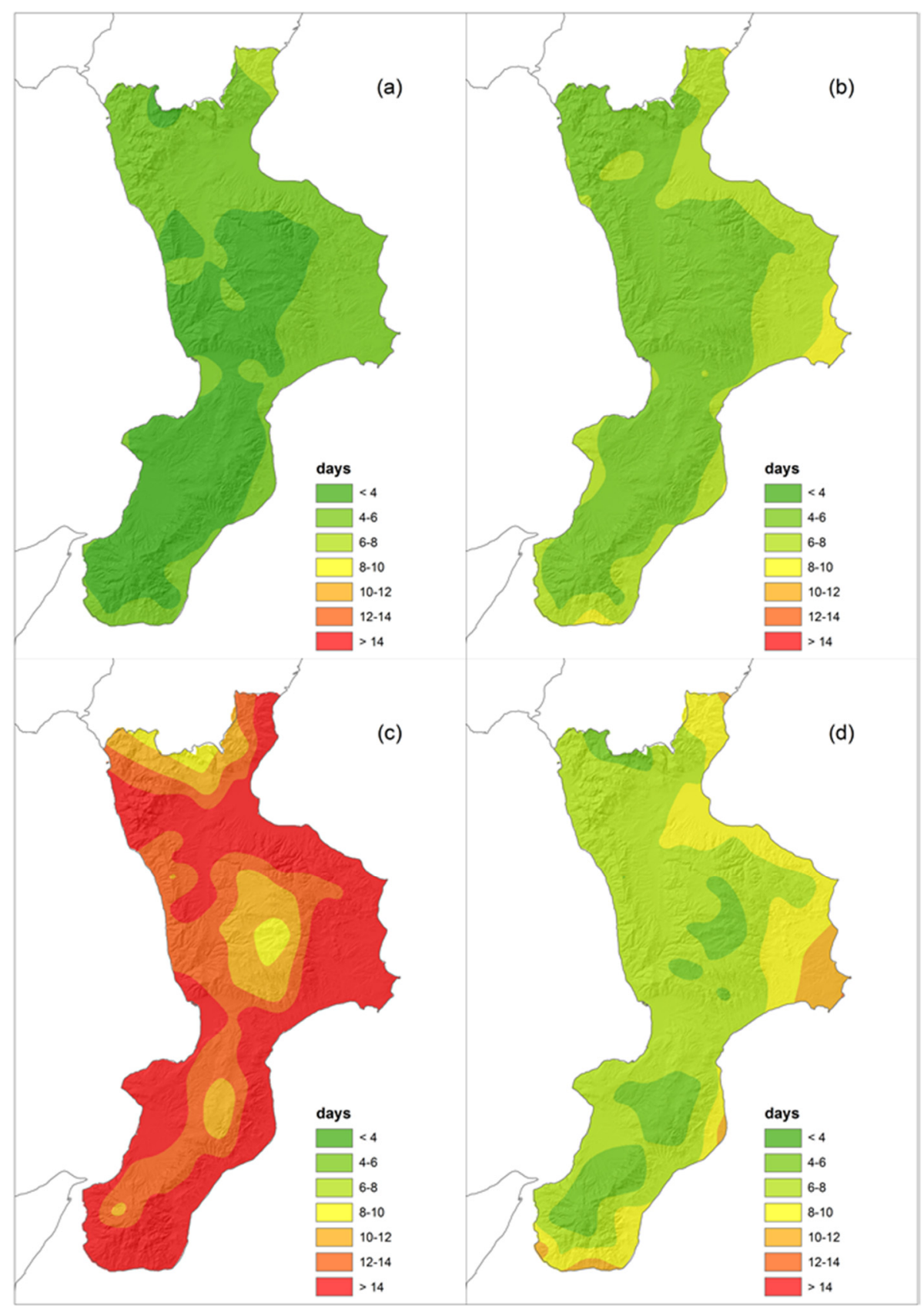

Figure 4. Mean length of the dry spells on a seasonal basis, (a) winter; (b) spring; (c) summer and (d) autumn.

With regards to the maximum length of the dry spells, it is interesting to note that the spatial patterns only partially reflect the behavior showed by the mean spells. In particular, the spatial distribution of the maximum length of the dry spells in autumn (Figure 5d) is very similar to the one obtained for the annual time scale (Figure 3b). In fact, both the west-east gradient and the highest values (more than 200 days) in the plain areas of the region have been detected. A more homogeneous distribution of the maximum values has been detected in winter, with the exception of three rain gauges, which showed lengths of 191, 195 and 221 days in the years 1943, 2003 and 2001, respectively (Figure 5a). In this paper, particular attention was paid to problems resulting from inhomogeneities of the data series and, in order to avoid possible errors, the rainfall series of these rain gauges have been checked again, but no errors have been detected. Similarly to winter, in spring a 
homogeneous spatial distribution of the maximum length of the dry spells have been evaluated, with the highest values in the plain areas of the region till a maximum of 134 days (Figure 5b). Finally, as for the average spring values, in summer the region can be divided in two areas, the coastal Ionian and southern Tyrrhenian area with the highest maximum dry spells (166 days), and the central and northern Tyrrhenian area with the lowest one (Figure 5c).

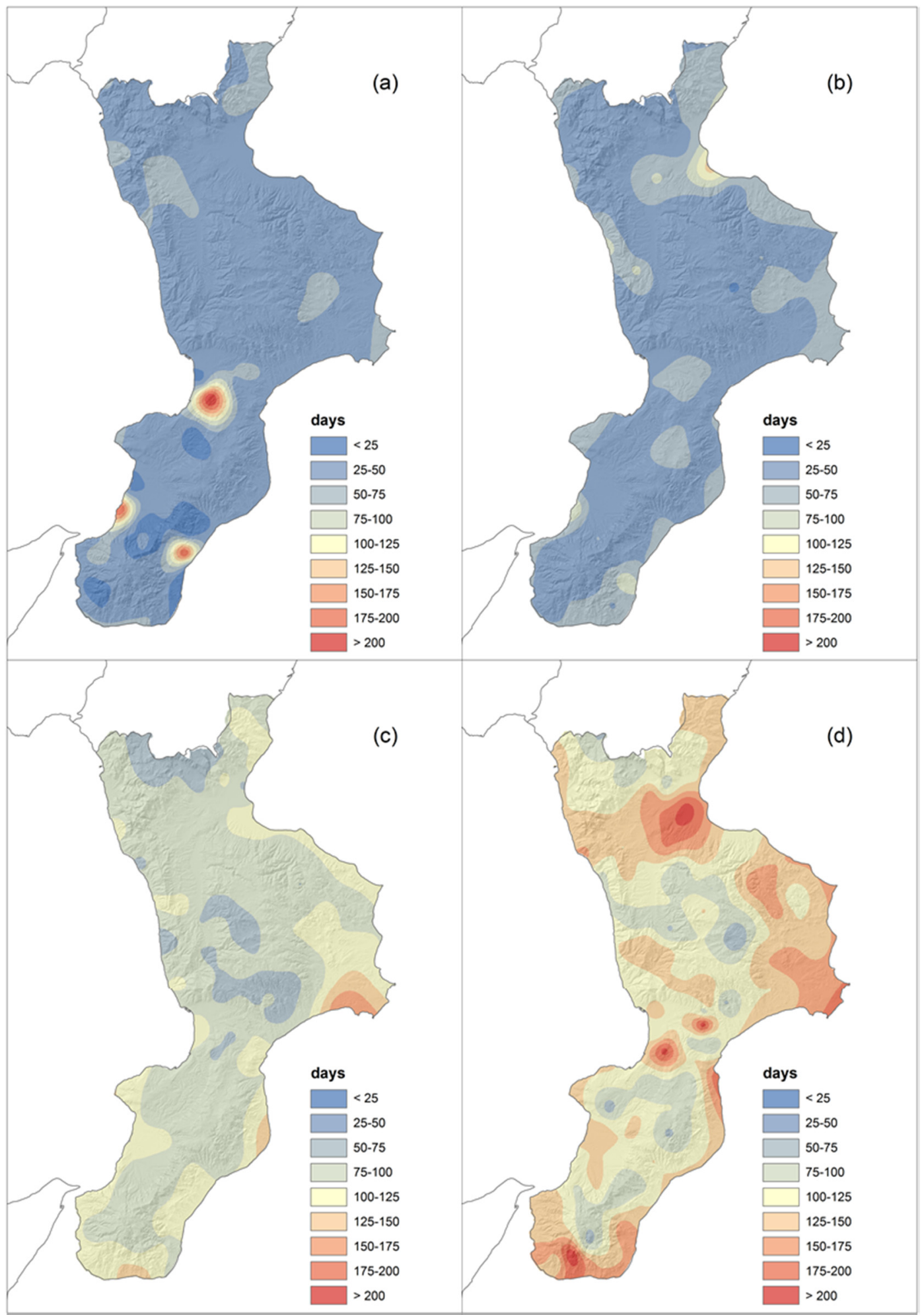

Figure 5. Maximum length of the dry spells on a seasonal basis: (a) winter; (b) spring; (c) summer and (d) autumn. 


\subsection{Temporal Variability of the Dry Spell Lengths}

Most of the dry spell series presented serial correlations in data, especially in winter. For this reason, the non-parametric MK test has been applied to annual and seasonal dry spell values after pre-whitening of the data through the von Storch's procedure [74].

The trend analysis of the maximum annual values evidenced a reduction of the length of the dry spells $(21.1 \%$ of the rain gauges), which mainly involves the hills and valleys of the region (with a maximum reduction of about -2 days/10 years), while no significant trend has been detected on the mountain (Figure 6a). With regards to seasonal precipitation, a significant trend cannot be identified for all the season; however, a significant negative trend has been detected in summer (Figure 6d) with a maximum reduction of more than -2 days/ 10 years.

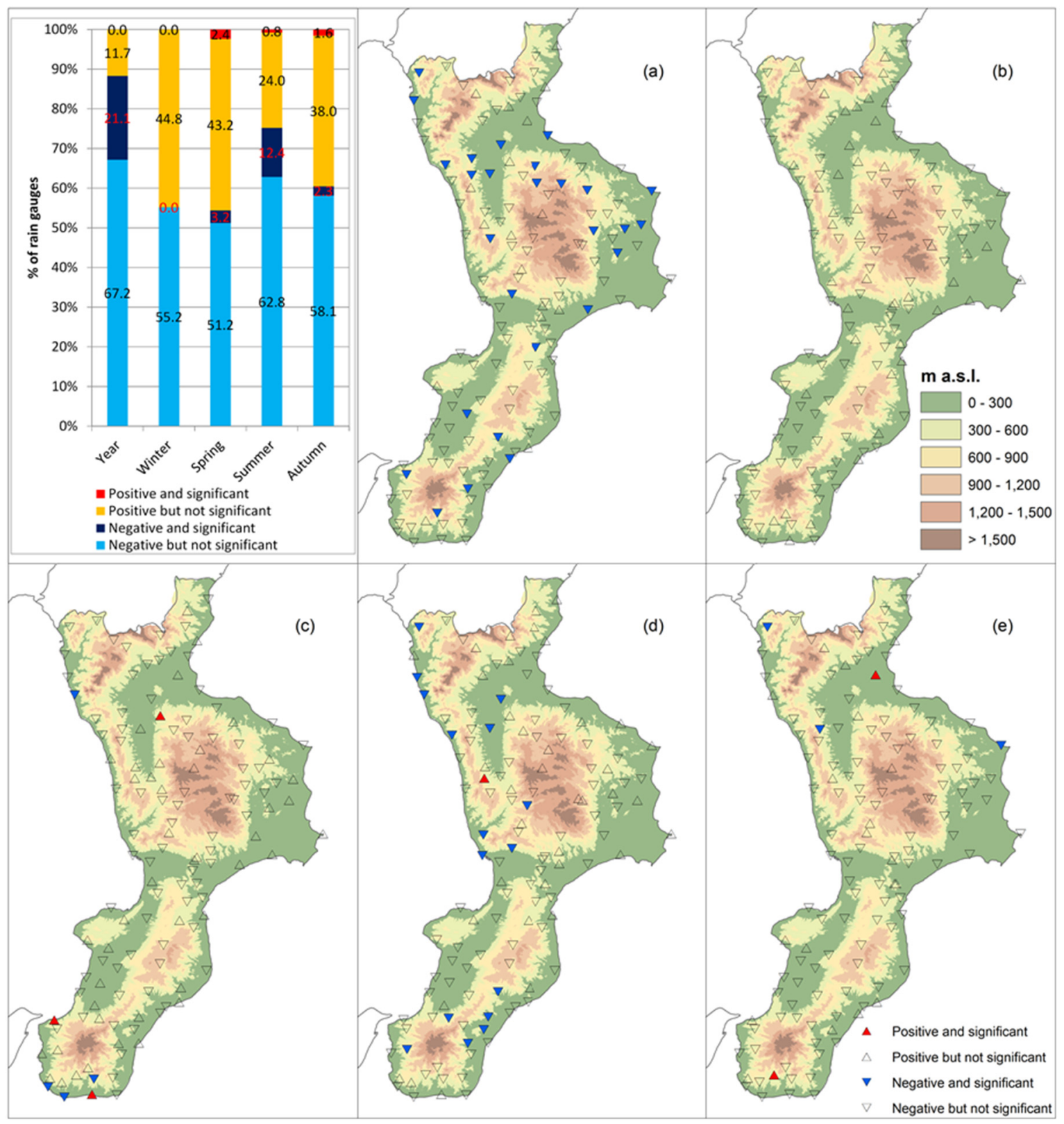

Figure 6. Summary and spatial distribution of the trend analysis on dry spell durations at (a) annual and seasonal scale: (b) winter; (c) spring; (d) summer and (e) autumn. 
These results disagree with other studies in the Mediterranean region, which evidenced an increase in the mean and largest dry periods [57,59]. However, the temporal behavior of the dry spells confirms other studies on rainfall in Calabria [23,27], which evidenced a decreasing trend for autumn-winter rainfall and an increasing trend in summer.

\section{Conclusions}

Investigating dry periods is useful in drought prediction for agricultural and environmental planning and management [54]. In this paper, the spatial and temporal patterns of dry spells in Calabria (southern Italy) have been analyzed using a daily precipitation dataset, formed by 129 rainfall series collected in the period 1941-2006. First, the frequency distribution of the dry spell lengths has been analyzed, and the higher percentile values have been mapped. As a result, a correspondence between the orography and the distribution of the dry spells has been detected: the highest values have been observed on the coastal areas, whereas the lowest ones have been found on the mountains.

Then, the maximum and the mean values of the dry spell lengths, both at annual and seasonal scale, have been evaluated and spatially distributed, evidencing a west-east gradient. In particular, lower lengths of dry spells have been observed in the main reliefs of the region, while the highest values have been detected on the Ionian side. Finally, the long-term trend of the dry spell lengths has been estimated. The results mainly revealed a negative behavior of the dry spell lengths at annual scale. If confirmed, these results could impact on the management of water resources (reservoirs and ground surface waters).

\section{Author Contributions}

The authors contributed equally to this work.

\section{Conflicts of Interest}

The authors declare no conflict of interest.

\section{References}

1. Solomon, S.; Qin, D.; Manning, M.; Chen, Z.; Marquis, M.; Averyt, K.B.; Tignor, M.; Miller. H.L. Contribution of Working Group I to the Fourth Assessment Report of the Intergovernmental Panel on Climate Change, 2007; Cambridge University Press: Cambridge, UK, 2007.

2. Zhang, X.; Zwiers, F.W.; Hegerl, G.C.; Lambert, F.H.; Gillet, N.P.; Solomon, S.; Stott, P.A.; Nozawa, T. Detection of human influence on twentieth century precipitation trends. Nature 2007, 448, 461-465.

3. Min, S.K.; Zhang, X.; Zwiers, F.W.; Hegerl, G.C. Human contribution to more-intense precipitation extremes. Nature 2011, 470, 378-381.

4. Pinto, J.G.; Ulbrich, U.; Leckebusch, G.C.; Spangehl, T.; Reyers, M.; Zacharias, S. Changes in storm track and cyclone activity in three SRES ensemble experiments with the ECHAM5/MPI-OM1 GCM. Clim. Dyn. 2007, 29, 195-210. 
5. Ulbrich, U.; Leckebusch, G.C.; Pinto, J.G. Extra-tropical cyclones in the present and future climate: A review. Theor. Appl. Climatol. 2009, 96, 117-131.

6. Ren, L.; Arkin, P.; Smith, T.M.; Shen, S.S.P. Global precipitation trends in 1900-2005 from a reconstruction and coupled model simulations. J. Geophys. Res. Atmos. 2013, 118, 1679-1689.

7. Westra, S.; Alexander, L.V.; Zwiers, F.W. Global Increasing trends in annual maximum daily precipitation. J. Clim. 2013, 26, 3904-3918.

8. Choi, G.; Collins, D.; Ren, G.; Trewin, B.; Baldi, M.; Fukuda, Y.; Afzaal, M.; Pianmana, T.; Gomboluudev, P.; Huong, P.T.; et al. Changes in means and extreme events of temperature and precipitation in the Asia-Pacific Network region, 1955-2007. Int. J. Clim. 2009, 29, 1906-1925.

9. Kelley, C.P.; Ting, M.; Seager, R.; Kushnir, Y. Mediterranean precipitation climatology, seasonal cycle, and trend as simulated by CMIP5. Geophys. Res. Lett. 2012, 39, L21703.

10. Partal, T.; Kahya, E. Trend analysis in Turkish precipitation data. Hydrol. Process. 2006, 20, 2011-2026.

11. Caloiero, T. Analysis of rainfall trend in New Zealand. Environ. Earth Sci. 2015, 73, 6297-6310.

12. Sayemuzzaman, M.; Jha, M.K. Seasonal and annual precipitation time series trend analysis in North Carolina, United States. Atmos. Res. 2014, 137, 183-194.

13. Barros, V.; Doyle, M.E.; Camilloni, I.A. Precipitation trends in South Eastern South America: Relationship with ENSO phases and with low-level circulation. Theor. Appl. Climatol. 2008, 93, 19-33.

14. Bhend, J.; Von, S.H. Consistency of observed winter precipitation trends in northern Europe with regional climate change projections. Clim. Dyn. 2008, 31, 17-28.

15. Huang, J.; Sun, S.L.; Xue, Y.; Zhang, J.C. Spatial and temporal variability of precipitation indices during 1961-2010 in Hunan Province, central South China. Theor. Appl. Climatol. 2014, $118,581-595$.

16. Xoplaki, E.; González-Rouco, J.F.; Luterbacher, J.; Wanner, H. Wet season Mediterranean precipitation variability: Influence of large-scale dynamics and trends. Clim. Dyn. 2004, 23, 63-78.

17. Brunetti, M.; Maugeri, M.; Monti, F.; Nanni, T. Temperature and precipitation variability in Italy in the last two centuries from homogenised instrumental time series. Int. J. Clim. 2006, 26, 345-381.

18. Longobardi, A.; Villani, P. Trend analysis of annual and seasonal rainfall time series in the Mediterranean area. Int. J. Clim. 2010, 30, 1538-1546.

19. Gonzalez-Hidalgo, J.C.; Brunetti, M.; de Luis, M. A new tool for monthly precipitation analysis in Spain: MOPREDAS database (Monthly precipitation trends December 1945-November 2005). Int. J. Clim. 2011, 31, 715-731.

20. Philandras, C.M.; Nastos, P.T.; Kapsomenakis, J.; Douvis, K.C.; Tselioudis, G.; Zerefos C.S. Long term precipitation trends and variability within the Mediterranean region. Nat. Hazards Earth Sys. Sci. 2011, 11, 3235-3250.

21. Caloiero, T.; Coscarelli, R.; Ferrari, E.; Mancini, M. Precipitation change in southern Italy linked to global scale oscillation indexes. Nat. Hazards Earth Sys. Sci. 2011, 11, 1683-1694.

22. Buttafuoco, G.; Caloiero, T.; Coscarelli, R. Spatial and temporal patterns of the mean annual precipitation at decadal time scale in southern Italy (Calabria region). Theor. Appl. Climatol. 2011, $105,431-444$. 
23. Caloiero, T.; Coscarelli, R.; Ferrari, E.; Mancini, M. Trend detection of annual and seasonal rainfall in Calabria (southern Italy). Int. J. Clim. 2011, 31, 44-56.

24. Brunetti, M.; Caloiero, T.; Coscarelli, R.; Gullà, G.; Nanni, T.; Simolo, C. Precipitation variability and change in the Calabria region (Italy) from a high resolution daily dataset. Int. J. Clim. 2012, 32, 57-73.

25. Capra, A.; Consoli, S.; Scicolone, B. Long-Term climatic variability in Calabria and effects on drought and agrometeorological parameters. Water Resour. Manag. 2013, 27, 601-617.

26. Ferrari, E.; Caloiero, T.; Coscarelli, R. Influence of the North Atlantic oscillation on winter rainfall in Calabria (southern Italy). Theor. Appl. Climatol. 2013, 114, 479-494.

27. Caloiero, T.; Buttafuoco, G.; Coscarelli, R.; Ferrari, E. Spatial and temporal characterization of climate at regional scale using homogeneous monthly precipitation and air temperature data: An application in Calabria (southern Italy). Hydrol. Res. 2014, in press, doi:10.2166/nh.2014.022.

28. Seidel, D.J.; Fu, Q.; Randel, W.J.; Reichler, T.J. Widening of the tropical belt in a changing climate. Nat. Geosci. 2008, 1, 21-24.

29. Jin, F.; Kitoh, A.; Alpert, P. Water cycle changes over the Mediterranean: A comparison study of a super-high-resolution global model with CMIP3. Philos. Trans. R. Soc. A: Math. Phys. Eng. Sci. 2010, 368, 5137-5149.

30. Raible, C.C.; Ziv, B.; Saaroni, H.; Wild, M. Winter synoptic-scale variability over the Mediterranean Basin under future climate conditions as simulated by the ECHAM5. Clim. Dyn. 2010, 35, 473-488.

31. Summary for Policymakers. Available online: https://www.ipcc.ch/pdf/assessment-report/ar4/wg1/ ar4-wg1-spm.pdf (accessed on 1 April 2015).

32. Austin, R.B.; Cantero-Martínez, C.; Arrúe, J.L.; Playán, E.; Cano-Marcellán, P. Yield rainfall relationships in cereal cropping systems in the Ebro river valley of Spain. Eur. J. Agron. 1998, 8, 239-248.

33. Quiring, S.M.; Papakryiakou, T.N. An evaluation of agricultural drought indices for the Canadian prairies. Agric. For. Meteorol. 2003, 118, 49-62.

34. Kogan, F. Droughts of the late 1980s in the United States as derived from NOAA Polar-Orbiting Satellite data. Bull. Am. Meteorol. Soc. 1995, 76, 655-668.

35. Kogan, F. Global drought watch from space. Bull. Am. Meteorol. Soc. 1997, 78, 621-636.

36. Abrams, M.D.; Ruffuer, M.C.; Morgan, T.A. Tree-Ring responses to drought across species and contrasting sites in the ridge and valley of central Pennsylvania. For. Sci. 1998, 44, 550-558.

37. Orwing, D.A.; Abrams, M.D. Variation in radial growth responses to drought among species, site and canopy strata. Trees 1997, 11, 474-484.

38. Nicholson, S.E.; Tucker, C.J.; Ba, M.B. Desertification, drought and surface vegetation: An example from the west African Sahel. Bull. Am. Meteorol. Soc. 1998, 79, 815-829.

39. Pickup, G. Desertification and climate change-The Australian perspective. Clim. Res. 1998, 11, 51-63.

40. Morales, A.; Olcina, J.; Rico, A.M. Diferentes persepciones de la sequía en España: Adaptación, catastrofismo e intentos de corrección. Investig. Geogr. 2000, 23, 5-46. (In Spanish)

41. García, R.V.; Smagorinsky, J.; Ellman, M. Nature Pleads Not Guilty; Pergamon Press: Oxford, UK, 1981. 
42. Kanti, B. Coping mechanisms practised by drought victims (1994/1995) in north Bengal, Bangladesh. Appl. Geogr. 1998, 18, 355-373.

43. Buttafuoco, G.; Caloiero, T. Drought events at different timescales in southern Italy (Calabria). J. Maps 2014, 10, 529-537.

44. Buttafuoco, G.; Caloiero, T.; Coscarelli, R. Analyses of drought events in Calabria (Southern Italy) using standardized precipitation index. Water Resour. Manag. 2015, 29, 557-573.

45. Kutiel, $H$. The multimodality of the rainfall course in Israel as reflected by the distribution of dry spells. Arch. Meteorol. Geophys. Bioclimatol. Ser. B 1985, 36, 15-27.

46. Bougila, B.; Sushama, L. On the current and future dry spell characteristics over Africa. Atmosphere 2013, 4, 272-298.

47. Groisman, P.Y.; Knight, R.W. Prolonged dry episodes over the conterminous United States: New tendencies emerging during the last 40 years. J. Clim. 2008, 21, 1850-1862.

48. Llano, M.P.; Penalba, O.C. A climatic analysis of dry sequences in Argentina. Int. J. Clim. 2011, 31, 504-513.

49. Carvalho, J.R.P.; Assad, E.D.; Evangelista, S.R.M.; Pinto, H.S. Estimation of dry spells in three Brazilian regions-Analysis of extremes. Atmos. Res. 2013, 132, 12-21.

50. Gong, D.Y.; Wang, J.A.; Han, H. Trends of summer dry spells in China during the late twentieth century. Meteorol. Atmos. Phys. 2005, 88, 203-214.

51. She, D.; Xia, J.; Song, J.; Du, H.; Chen, J.; Wan, L. Spatio-Temporal variation and statistical characteristic of extreme dry spell in Yellow River Basin, China. Theor. Appl. Climatol. 2013, 112, 201-213.

52. Sarhadi, A.; Heydarizadeh, M. Regional frequency analysis and spatial pattern characterization of dry spells in Iran. Int. J. Climatol. 2014, 34, 835-848.

53. Heinrich, G.; Gobiet, A. The future of dry and wet spells in Europe: A comprehensive study based on the ENSEMBLES regional climate models. Int. J. Climatol. 2012, 32, 1951-1970.

54. Serra, C.; Martínez, M.D.; Lana, X.; Burgueño, A. European dry spells distributions, years 1951-2000. Theor. Appl. Climatol. 2013, 114, 531-551.

55. Serra, C.; Martínez, M.D.; Lana, X.; Burgueño, A. European dry spell regimes (1951-2000): Clustering process and time trends. Atmos. Res. 2014, 144, 151-174.

56. Zolina, O.; Simmer, C.; Belyaev, K.; Sergey, K.; Gulev, S.; Koltermann, P. Changes in the duration of European wet and dry spells during the last 60 years. J. Clim. 2013, 26, 2022-2047.

57. Sánchez, E.; Domínguez, M.; Romera, R.; López de la Franca, N.; Gaertner, M.A.; Gallardo, C.; Castro, M. Regional modeling of dry spells over the Iberian Peninsula for present climate and climate change conditions. Clim. Chang. 2011, 107, 625-634.

58. Nastos, P.T.; Zerefos, C.S. Spatial and temporal variability of consecutive dry and wet days in Greece. Atmos. Res. 2009, 94, 616-628.

59. Cindrić, K.; Pasarić, Z.; Gajić-Čapka, M. Spatial and temporal analysis of dry spells in Croatia. Theor. Appl. Climatol. 2010, 102, 171-184.

60. Brunetti, M.; Maugeri, M.; Nanni, T.; Navarra, A. Droughts and extreme events in regional daily Italian precipitation series. Int. J. Climatol. 2002, 22, 543-558.

61. Sirangelo, B.; Caloiero, T.; Coscarelli, R.; Ferrari E. A stochastic model for the analysis of the temporal change of dry spells. Stoch. Environ. Res. Risk Assess. 2015, 29, 143-155. 
62. Caloiero, T.; Pasqua, A.A.; Petrucci, O. Damaging hydrogeological events: A procedure for the assessment of severity levels and an application to Calabria (Southern Italy). Water 2014, 6, 3652-3670.

63. Craddock, J.M. Methods of comparing annual rainfall records for climatic purposes. Weather 1979, 34, 332-346.

64. Simolo, C.; Brunetti, M.; Maugeri, M.; Nanni, T. Improving estimation of missing values in daily precipitation series by a probability density function preserving approach. Int. J. Climatol. 2010, 30, 1564-1576.

65. Mathugama, S.C.; Peiris, T.S.G. Critical evaluation of dry spell research. Int. J. Basic Appl. Sci. 2011, 6, 153-160.

66. Anagnostopoulou, C.H.R.; Maheras, P.; Karacostas, T.; Vafiadis, M. Spatial and temporal analysis of dry spells in Greece. Theor. Appl. Climatol. 2003, 74, 77-91.

67. Martín-Vide, J.; Gómez, L. Regionalisation of peninsular Spain based on the length of dry spells. Int. J. Climatol. 1999, 19, 537-555.

68. Serra, C.; Burgueño, A.; Martínez, M.D.; Lana, X. Trends in dry spells across Catalonia (NE Spain) during the second half of the 20th century. Theor. Appl. Climatol. 2006, 85, 165-183.

69. Lana, X.; Martínez, M.D.; Burgueño, A.; Serra, C.; Martín-Vide, J.; Gomez, L. Spatial and temporal patterns of dry spell lengths in the Iberian Peninsula for the second half of the twentieth century. Theor. Appl. Climatol. 2008, 91, 99-116.

70. Mann, H.B. Nonparametric tests against trend. Econometrica 1945, 13, 245-259.

71. Kendall, M.G. Rank Correlation Methods; Charles Griffin \& Company Limited: London, UK, 1962.

72. Yue, S.; Wang, C.Y. The Mann-Kendall test modified by effective sample size to detect trend in serially correlated hydrological series. Water Resour. Manag. 2004, 18, 201-218.

73. Yue, S.; Wang, C.Y. The applicability of prewhitening to eliminate the influence of serial correlation on the Mann-Kendall test. Water Resour. Res. 2002, 38, 4-1-4-7.

74. Von, S.H.; Navarra, A. Analysis of Climate Variability: Applications of Statistical Techniques; Springer Verlag: Berlin, Germany, 1999.

75. Colacino, M.; Conte, M.; Piervitali, E. Elementi di Climatologia Della Calabria; IFA-CNR: Roma, Italy, 1997. (In Italian)

76. Coscarelli, R.; Caloiero, T. Analysis of daily and monthly rainfall concentration in Southern Italy (Calabria region). J. Hydrol. 2012, 416, 145-156.

(C) 2015 by the authors; licensee MDPI; Basel; Switzerland. This article is an open access article distributed under the terms and conditions of the Creative Commons Attribution license (http://creativecommons.org/licenses/by/4.0/). 